\title{
Indoor radon monitoring in selected fault zones, Slovakia - preliminary results from the summer monitoring period
}

\author{
Iveta SMETANOVÁ ${ }^{1, *}$, Andrej MOJZEŠ², František MARKO², \\ Kamil FEKETE ${ }^{1}$, Kristián CSICSAY ${ }^{1}$ \\ ${ }^{1}$ Earth Science Institute, Slovak Academy of Sciences, \\ Dúbravská cesta 9, P. O. Box 106, 84005 Bratislava, Slovak Republic \\ ${ }^{2}$ Faculty of Natural Sciences, Comenius University, \\ Ilkovičova 6, 84215 Bratislava, Slovak Republic
}

\begin{abstract}
Indoor radon survey in Sološnica, Vydrník and Zázrivá villages has been performed within the framework of the project "Multidisciplinary research of geophysical and structural parameters, and environmental impacts of faults of the Western Carpathians". Integration measurement of ${ }^{222} \mathrm{Rn}$ activity concentration has been carried out using RamaRn detectors in houses, offices, schools and kindergartens. Indoor radon activity in the summer monitoring period (June-August 2018) varied from values under the detection limit of $55 \mathrm{~Bq} / \mathrm{m}^{3}$ to $480 \mathrm{~Bq} / \mathrm{m}^{3}$. In $94 \%$ of rooms the radon activity below $200 \mathrm{~Bq} / \mathrm{m}^{3}$ was found. The results have been examined in respect of the most used building material and presence or absence of a cellar underneath the room. Indoor radon higher than $300 \mathrm{~Bq} / \mathrm{m}^{3}$ was measured only in rooms in direct contact with the subsoil.
\end{abstract}

Key words: radon, activity concentration, building, integral monitoring, survey

\section{Introduction}

Soil gas infiltration is recognized as the most important source of indoor radon concentration (IRC). Radon may enter in dwellings by diffusion or a pressure driven flow if suitable pathways between the soil and living spaces are present. Other sources, including building material and water extracted from wells, are of less importance (WHO, 2009). The building characteristics as thermal retrofit, presence or absence of a cellar and ventilation type and intensity may also significantly affect IRC (Borgoni et al., 2014; Collignan et al., 2016). Energy saving reconstructions of buildings often results in an increase of IRC (Collignan et al., 2016; Fojtiková and Navrátilová-Rovenská, 2015).

${ }^{*}$ corresponding author: e-mail: Iveta.Smetanova@savba.sk 
Geological fault mapping methods is difficult to apply in covered or builtup areas. The hidden morphology of the fault could be revealed by the high resolution soil radon survey. Many studies proved an increased soil radon activity in the proximity of active faults (Burton et al., 2004; Font et al., 2008; Neri et al., 2011; Bonforte et al., 2013; Moreno et al., 2018). The presence of faults nearby buildings may increase IRC (Drolet and Martel, 2016; Neri et al., 2019). However, not all surveys confirmed an elevated indoor radon in fault areas, because radon concentration level in a house is the result of many parameters and processes of different origin (Font et al., 2008).

In Slovakia, several indoor radon surveys were performed. The first indoor radon monitoring in randomly selected dwellings was conducted in the nineties, using the integral method (Vičanová, 2003). In 2005 radon research in dwellings situated on the fault zone was carried out, together with soil radon measurements, in the Malá Magura Mts. (Horná Nitra region of Central Slovakia), however the influence of the fault presence on radon concentration was not proven (Mojzeš et al., 2017). In recent years indoor radon monitoring was conducted within the frame of the Visegrad countries project and the common questionnaire and common measurement protocol was elaborated (Müllerová et al., 2016).

In this paper the preliminary results from the summer monitoring period (June-August 2018) in Sološnica, Vydrník and Zázrivá villages are presented and the potential influencing factors on IRC are evaluated. For Sološnica the results are compared also with the spring monitoring period (March-May 2018). The aim of this radon survey was to verify if the houses built on the fault zones are prone to high indoor radon. Indoor radon monitoring in above mentioned localities was performed within the framework of the project "Multidisciplinary research of geophysical and structural parameters, and environmental impacts of faults of the Western Carpathians".

\section{Methods and site description}

In three selected localities (Sološnica, Vydrník, Zázrivá) situated on the fault zones (Fig. 1) indoor radon monitoring has been carried out. The measurements were performed mainly in houses, but also offices, schools and kindergartens were included in this survey. Throughout the whole year 


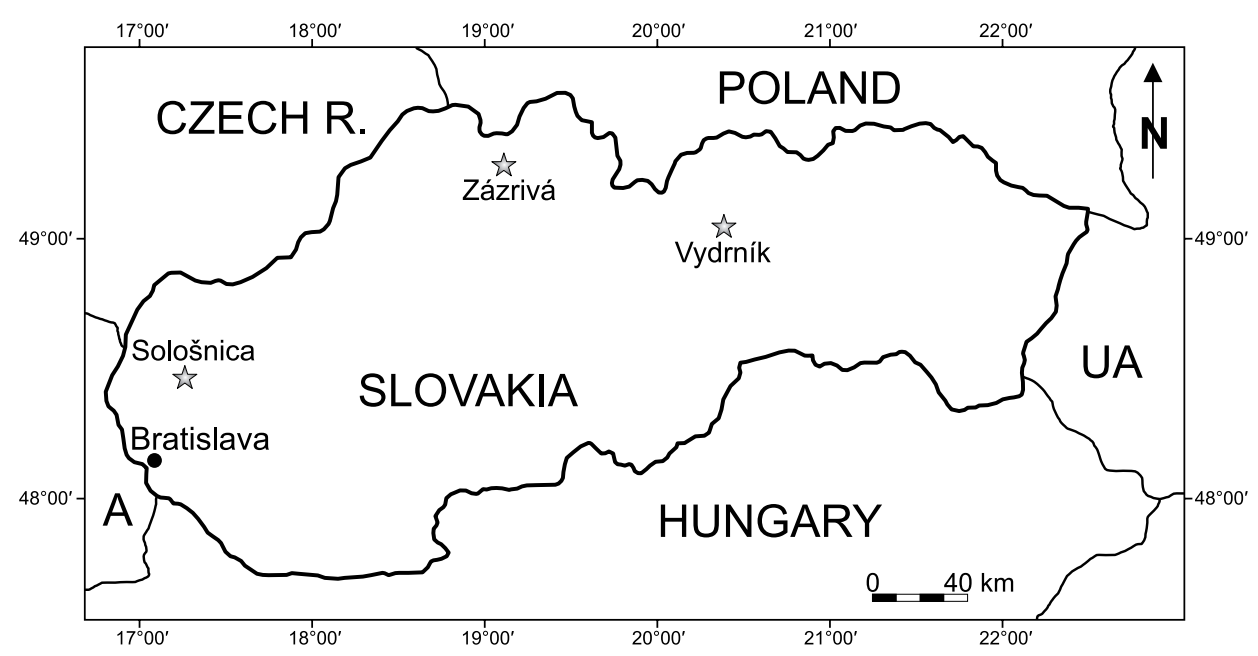

Fig. 1. Location of the three studied areas.

sets of detectors were changed after three months of exposure (spring, summer, autumn and winter period). Radon survey in Sološnica started in the spring monitoring period (March-May 2018). Due to technical reasons, radon monitoring in Vydrník and Zázrivá started later, in the summer period (June-August 2018).

In the monitored buildings, two or three detectors were placed, primarily in the rooms situated on the ground floor, where the inhabitants spend most of their time. Detectors were placed $15-20 \mathrm{~cm}$ from the walls, as far as possible from the windows, doors and heating bodies. Building characteristics as building material, window tightness, cellar, year of construction and reconstruction, number of inhabitants, intensity of ventilation and time spent in monitored rooms were obtained through a questionnaire, distributed to voluntary participants of the survey together with information leaflet about radon (Müllerová et al., 2016). Passive alpha track detector RamaRn (SÚJCHBO, Milín, Czech Republic), with Kodak LR 115 film located at the bottom of the diffusion chamber was used in this survey (Thinová and Burian, 2008).

The Sološnica village is situated on the border of two geomorphological provinces - the Malé Karpaty Mts. and the Záhorská nížina Lowland, at the contact of the Paleogene sediments of the Buková furrow and the Pan- 
nonian sediments of the Vienna basin. Paleogene sediments (Fordinál et al., 2012) are represented by the Upper Eocene-Oligocene Zuberec Formation (Kyscellian Hrabník Formation sensu Marko et al., 1990) formed by the flysch-type sediments, which are folded and faulted. Lower PleistoceneHolocene Quaternary formations are represented by proluvial-wetland sediments with organic admixture, loams with fragments of sandy pebbles in low alluvial fans and deluvial-fluvial sediments with sandy debris. According to the radon risk map elaborated by the State Geological Survey of Dionýz Štúr, Sološnica village belongs to the low and medium radon risk areas (Gluch et al., 2009). Buildings situated on the three profiles crossing assumed faults location were selected for indoor radon monitoring.

Vydrník village is located in the zone of the supposed map trace of $\mathrm{E}$ W Vikartovce fault, rimming from the south uplifted and tilted block of the Kozie Chrbty Mts., composed of Mesozoic sequences of the Choč unit. Southward of the Vikartovce fault downthrown block of Hornád river occurs, with preserved Paleogene sediments (Vojtko et al., 2011). According to the radon risk map Vydrník is situated in the medium radon risk area (Gluch et al., 2009). The monitored buildings were situated on two profiles, one of them running parallel and one perpendicularly to the Vikartovce fault.

Zázrivá village is situated across the tectonic contact zone of the Pieniny klippen belt unit with both Outer and Inner Western Carpathians units (Marko et al., 2005). One part of the detectors was placed in the buildings at the vicinity of a supposed map trace of the neotectonically active $\mathrm{E}-\mathrm{W}$ Kozinec fault inside the Pieniny klippen belt zone, in a high radon risk area (Gluch et al., 2009). Another part of the monitored buildings in Zázrivá was situated close to the southern tectonic contact of the Pieniny klippen belt zone with peri-Klippen Paleogene sediments, in the medium radon risk area.

\section{Results and discussion}

For the summer monitoring period the detectors were distributed to 225 rooms in 112 buildings (Table 1). In total, 218 detectors were collected $(96.9 \%)$.

Most of the collected detectors $(84.4 \%)$ were placed in the living room, kitchen, bedroom, child room and classroom (Table 2). During the summer 
Table 1. Detectors distributed in the summer monitoring period (June-August 2018) and maximum of IRC.

\begin{tabular}{lcc}
\hline Locality & houses (rooms) & $\max \operatorname{IRC}\left(\mathrm{Bq} / \mathrm{m}^{3}\right)$ \\
\hline Sološnica & $66(136)$ & 405 \\
Vydrník & $22(44)$ & 370 \\
Zázrivá & $24(45)$ & 480 \\
total & $112(225)$ & 480 \\
\hline
\end{tabular}

period IRC ranged from values under the detection limit of $55 \mathrm{~Bq} / \mathrm{m}^{3}$ to $480 \mathrm{~Bq} / \mathrm{m}^{3}$. A histogram of the frequency distribution for IRC in monitored rooms is depicted in Fig. 2. In $67 \%$ of rooms IRC was lower than the detection limit $55 \mathrm{~Bq} / \mathrm{m}^{3}$. Radon activity less than $200 \mathrm{~Bq} / \mathrm{m}^{3}$ was found in the majority of monitored rooms (94\%). All monitored buildings were mechanically ventilated, by opened windows. Generally low IRC values in the summer period can be explained by intensive ventilation of investigated rooms in the summer season (Papaefthymiou et al., 2003).

Table 2. Building characteristics.

\begin{tabular}{llll}
\hline Type of a room & rooms (\%) & Building material & rooms $(\%)$ \\
\hline living room & $66(30.3)$ & aerated concrete (AC) & $56(25.7)$ \\
kitchen & $54(24.7)$ & brick & $44(20.2)$ \\
bedroom & $45(20.6)$ & slag block & $24(11.0)$ \\
child room & $11(5.0)$ & AC + brick & $16(7.3)$ \\
classroom & $8(3.7)$ & stone & $14(6.4)$ \\
office & $4(1.8)$ & no info & $5(2.3)$ \\
other & $30(13.8)$ & other & $47(21.6)$ \\
\hline
\end{tabular}

The preliminary results were examined in respect of five of the most used building materials (Table 2) and presence or absence of a cellar underneath the room. Increased IRC is often measured in room when it has direct contact with the subsoil. Radon from soil air can penetrate through the cracks in mat-slab foundations into the room, as a consequence of pressure difference between a building and the surrounding soil. A cellar can protect rooms from direct soil airflow (Papaefthymiou et al., 2003; Borgoni et al., 2014; Müllerová et al., 2016). However, unless they were well insulated, 
cellars may also act as an entry point for radon into a building (Buchli and Burkart, 1989).

Almost $41 \%$ of the rooms monitored in the summer period were situated above a cellar. The distribution of IRC between rooms with and without a cellar underneath in Sološnica, Vydrník and Zázrivá is depicted in Fig. 3. During the summer monitoring period IRC higher than $300 \mathrm{~Bq} / \mathrm{m}^{3}$ was found only in the rooms with direct contact to the subsoil. IRC levels were

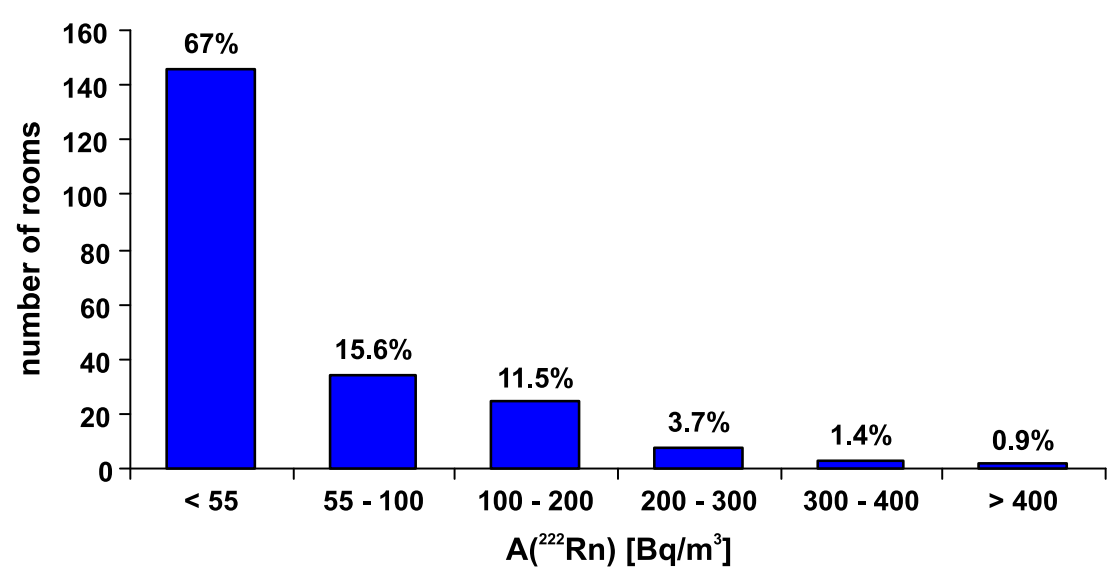

Fig. 2. The frequency distribution of IRC during the summer monitoring period (JuneAugust 2018).

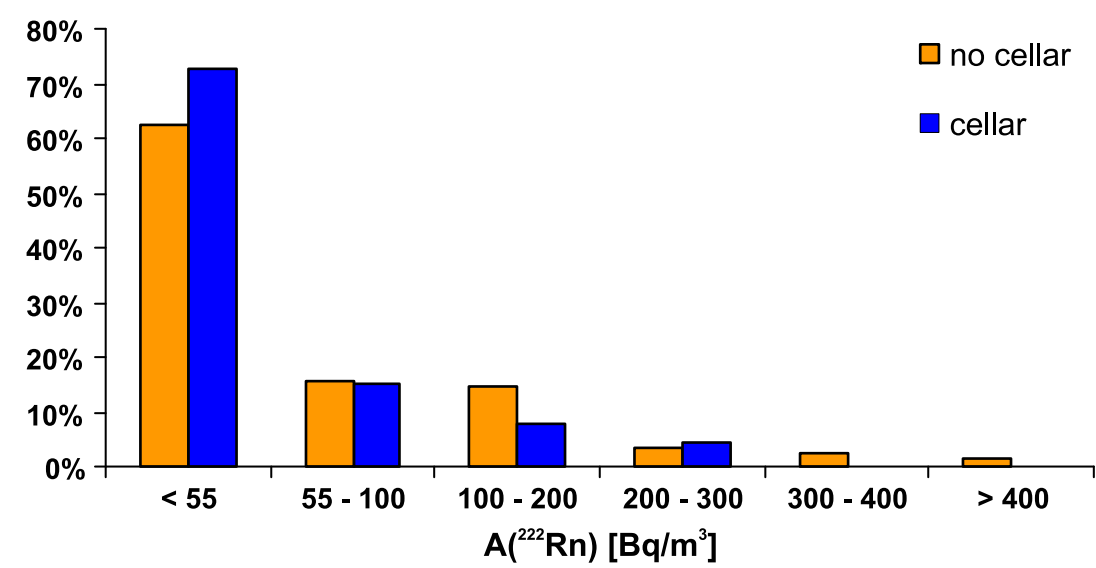

Fig. 3. The comparison of indoor ${ }^{222} \mathrm{Rn}$ concentration according to the contact of monitored room with the subsoil. 
lower than the detection limit in $73 \%$ of the rooms situated above a cellar and in $62 \%$ of the rooms without a cellar. The results obtained in Sološnica for the spring period showed that in $58 \%$ of the rooms situated above the cellar IRC was lower than the detection limit, while in rooms without a cellar only in 31\% (Smetanová et al., 2018).

The most used building material differs among studied localities and the utilization of a specific material and the building methods are connected with the year of construction. While in Sološnica the major part of investigated buildings was built from aerated concrete (29\%), slag blocks $(14 \%)$ and brick (12\%), in Zázrivá brick (28\%) and aerated concrete $(26 \%)$ prevailed and in Vydrník buildings constructed from bricks (41\%) and stone $(17 \%)$ dominated. However, also wood, adobe, concrete and various combinations of previously mentioned materials were used for the construction. Relatively new buildings constructed after year 1990 were made mainly of brick and aerated concrete, or their combination. Buildings constructed before 1960 were usually built from brick, stone and adobe.

According to the questionnaire (Table 2), the major part of the investigated buildings were constructed from aerated concrete, brick, slag blocks, local stone (limestone, travertine) or a combination of aerated concrete and brick. Among the above listed five materials, IRC higher than $300 \mathrm{~Bq} / \mathrm{m}^{3}$ was found in the building made of bricks. In all investigated buildings made of aerated concrete mixed with brick IRC was less than the detection limit (Fig. 4).

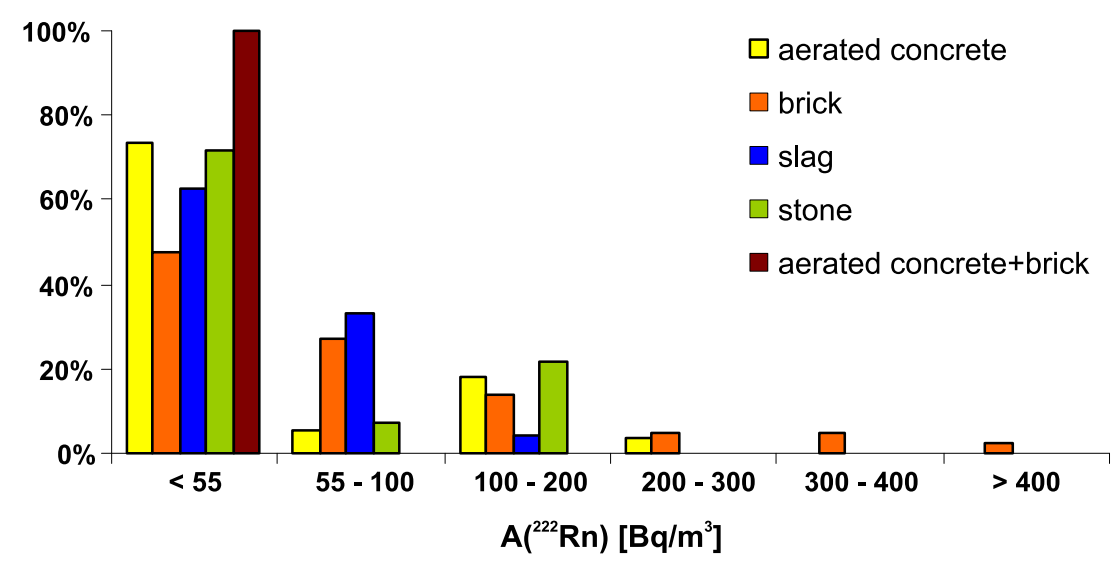

Fig. 4. The comparison of IRC according to the five the most used building materials. 
In the summer monitoring period IRC exceeding $300 \mathrm{~Bq} / \mathrm{m}^{3}$ was found in all three monitored areas. The highest IRC in this monitoring period equal to $(480 \pm 60) \mathrm{Bq} / \mathrm{m}^{3}$ was measured in Zázrivá, in a relatively new house constructed in 2012, made of a combination of wood and aerated concrete. The house has no cellar under the monitored room. This house was built in a part of Zázrivá which is situated in the high radon risk area, however according to the questionnaire it was poorly ventilated, which probably caused an elevated IRC.

In all monitoring sites the indoor radon monitoring was performed in kindergartens (Sološnica, Zázrivá) or schools (Sološnica, Vydrník). Increased IRC measured in schools and kindergartens during the summer period can be connected with poor ventilation of rooms through the summer vacation, when the windows were closed for several weeks (Múllerová et al., 2016). Unfortunately, comparative data from the kindergarten in Zázrivá is missing, because both detectors were lost.

The highest IRC in Sološnica was detected in a kindergarten. The groundfloor building was constructed of brick in the seventies and thermally retrofitted in 2008 (replaced windows, thermal insulation) and has no cellar. Detectors were placed in all three classrooms. According to the questionnaire, the classrooms were intensively ventilated. In the summer monitoring period IRC equal to $285 \mathrm{~Bq} / \mathrm{m}^{3}, 305 \mathrm{~Bq} / \mathrm{m}^{3}$ and $405 \mathrm{~Bq} / \mathrm{m}^{3}$ was found. However, the classroom with the highest IRC was closed for two months (from June to the end of August 2018) and the remaining two classrooms operated only until the last week of July 2018 , so the results obtained during the summer monitoring period are not representative, they are strongly affected by a ventilation regime. Nevertheless, elevated IRC in comparison with the rest of the monitored buildings in Sološnica (Table 3) was confirmed in all classrooms also in the spring monitoring period (Smetanová et al., 2018).

Table 3. The comparison of indoor radon concentration measured in the kindergarten in Sološnica in the spring and summer monitoring periods.

\begin{tabular}{lccc}
\hline $\mathrm{A}\left({ }^{222} \mathrm{Rn}\right)\left(\mathrm{Bq} / \mathrm{m}^{3}\right)$ & classroom 1 & classroom 2 & classroom 3 \\
\hline spring (March-May) & $315 \pm 55$ & $365 \pm 35$ & $280 \pm 50$ \\
summer (June-August) & $285 \pm 50$ & $305 \pm 50$ & $405 \pm 55$ \\
\hline
\end{tabular}


In comparison with the kindergarten, IRC in the primary school in Sološnica was significantly lower, both in the spring and summer periods. A part of this building was made of brick in 1942, with a cellar under several classrooms. The new part built in 1992 from aerated concrete has no cellar. Three classrooms on the ground-floor were selected for the monitoring purposes. One of them was situated in the new part of the building. The remaining two monitored classrooms were in the older part, one of them was situated above the cellar. All classrooms were equipped with new plastic windows, but the building was not thermally insulated. During the summer vacation (July-August) the building maintenance work (painting) was performed and classrooms were intensively ventilated by opened windows. IRC equal to $(70 \pm 25) \mathrm{Bq} / \mathrm{m}^{3}$ or below the detection limit was found in the summer period. Similarly as in the kindergarten, the results obtained during the summer monitoring period are not representative, because of a different ventilation regime during the summer vacation. However, IRC in the classrooms was low also in the spring period, equal to $(130 \pm 40) \mathrm{Bq} / \mathrm{m}^{3}$ or was below the detection limit.

Another building in Sološnica with IRC exceeding $300 \mathrm{~Bq} / \mathrm{m}^{3}$ in the summer period was built in the 19-th century from a mixture of brick and local stone (limestone) and has no cellar under the both investigated rooms used as offices. The building was reconstructed in 2002 (replaced windows, thermal insulation). IRC in both rooms was higher than in the spring monitoring period $(105 \pm 35) \mathrm{Bq} / \mathrm{m}^{3}$ and $(100 \pm 35) \mathrm{Bq} / \mathrm{m}^{3}$, equal to $(310 \pm 50) \mathrm{Bq} / \mathrm{m}^{3}$ and $(150 \pm 30) \mathrm{Bq} / \mathrm{m}^{3}$ in the summer period, respectively.

In Vydrník IRC above $300 \mathrm{~Bq} / \mathrm{m}^{3}$ was registered in the house built from brick at the beginning of the 20-th century. While in the room above the cellar IRC was low $(56 \pm 35) \mathrm{Bq} / \mathrm{m}^{3}$, in the room with a direct contact with the subsoil it reached $(370 \pm 55) \mathrm{Bq} / \mathrm{m}^{3}$. According to the questionnaire, both monitored rooms were intensively ventilated.

IRC in the three monitored classrooms in the primary school in Vydrník reached $(180 \pm 45) \mathrm{Bq} / \mathrm{m}^{3},(225 \pm 50) \mathrm{Bq} / \mathrm{m}^{3}$ and $(250 \pm 50) \mathrm{Bq} / \mathrm{m}^{3}$. The school was constructed in 1972 from brick and concrete. The lowest IRC was determined in the classroom on the basement. Two classrooms on the ground floor were both situated above a cellar. Classrooms are equipped with new plastic windows, but the building is not thermally insulated. The higher indoor radon levels than in the rest of monitored buildings can be explained 
by poor ventilation of the classrooms during the summer vacation.

The preliminary results from the spring and summer monitoring period in Sološnica and summer monitoring period in Vydrník and Zázrivá did not satisfactorily prove the possible influence of assumed fault zones crossing monitored areas on IRC levels in monitored rooms. However, in some of the buildings, situated close to assumed fault lines (the kindergarten in Sološnica, the house with the highest IRC in Vydrník), significantly higher IRC was found in the comparison with the rest of monitored buildings in the studied area. The application of a wider complex of geophysical methods, together with the soil radon emanometry measurements in the vicinity of the buildings with elevated IRC, is necessary to show whether increased IRC is connected with fault zones or with the building characteristics or ventilation regime of monitored rooms.

\section{Conclusion}

In the summer monitoring period (June-August 2018) IRC was measured in 218 rooms of three localities Sološnica, Vydrník and Zázrivá situated on assumed fault zones. Possible influencing factors (cellar, building material) on IRC were analyzed. The majority of IRC in investigated rooms was below the detection limit of $55 \mathrm{~Bq} / \mathrm{m}^{3}$, probably as a result of intense ventilation

of rooms in the summer months. However, IRC exceeding $300 \mathrm{~Bq} / \mathrm{m}^{3}$ was found in all monitored areas, in the rooms in direct contact with the subsoil. IRC below the detection limit was found in all buildings made of aerated concrete mixed with brick.

On the basis of the preliminary results from the spring and summer monitoring period in Sološnica and summer monitoring period in Vydrník and Zázrivá a possible relation between elevated indoor radon levels and position of a monitored building in relation to an assumed fault line was not sufficiently proven.

Acknowledgements. This work was supported by the Slovak Research and Development Agency of Ministry of Education, Science, Research and Sport of the Slovak Republic (project APVV-16-0146) and the Scientific Grant Agency of Ministry of Education, Science, Research and Sport of the Slovak Republic (VEGA project 2/0083/18). 


\section{References}

Bonforte A., Cinzia F., Giammanco S., Guglielmino F., Liuzzo M., Neri M., 2013: Soil gases and SAR measurements reveal hidden faults on the sliding flank of Mt. Etna (Italy). J. Volcanol. Geotherm. Res., 251, 27-40, doi : 10.1016/j.jvolgeores. 2012 .08 .010 .

Borgoni R., De Francesco D., De Bartolo D., Tzavidis N., 2014: Hierarchical modeling of indoor radon concentration: how much do geology and building factors matter?

J. Environ. Radioact., 138, 227-237, doi: 10.1016/j.jenvrad.2014.08.022.

Buchli R., Burkart W., 1989: Influence of subsoil geology and construction technique on indoor air 222Rn levels in 80 houses of the central Swiss Alps. Health Phys., 56, 4, 423-429, doi: 10.1097/00004032-198904000-00003.

Burton M., Neri M., Condarelli D., 2004: High spatial resolution radon measurements reveal hidden active faults on Mt. Etna. Geophys. Res. Lett., 31, 7, L07618, doi: 10.1029/2003GL019181.

Collignan B., Le Ponner E., Mandin C., 2016: Relationships between indoor radon concentrations, thermal retrofit and dwelling characteristics. J. Environ. Radioact. 165, 124-130, doi : 10.1016/j.jenvrad.2016.09.013.

Drolet J.-P., Martel R., 2016: Distance to faults as a proxy for radon gas concentration in dwellings. J. Environ. Radioact. 152, 8-15, doi : 10.1016/j · jenvrad.2015.10.023.

Fojtíková I., Navrátilová Rovenská K., 2015: Methodology for measurement in schools and kindergartes: experiences. Radiat. Prot. Dosim., 164, 4, 612-617, doi: 10.1093/ rpd/ncv340.

Font Ll., Baixeras C., Moreno V., Bach J., 2008: Soil radon levels across the Amer fault. Radiat. Meas., 43, Suppl. 1, S319-S323, doi: 10.1016/j.radmeas.2008.04.072.

Fordinál K. (Ed.), Maglay J., Elečko M., Nagy A., Moravcová M., Vlačiky M., Kučera M., Polák M., Plašienka D., Filo I., Olšavský M., Buček S., Havrila M., Kohút M., Bezák V., Németh Z., 2012: Geological map of the Záhorská nížina Lowland (scale 1:50,000). State Geological Institute of Dionýz Štúr, Bratislava.

Gluch A., et al., 2009: Maps of natural radioactivity (Prehladné mapy prírodnej rádioaktivity). State Geological Institute of Dionýz Stúr, Bratislava, available online at: http://apl.geology.sk/radio.

Marko F., Kováč M., Fodor L., Sútovská K., 1990: Deformations and kinematics of a Miocene shear zone in the northern Little Carpathians (Bukovská Furrow, Hrabník Formation) (Deformácia a kinematika miocénnej strižnej zóny severnej časti Malých Karpát (Bukovská brázda, hrabnícke súvrstvie)). Miner. Slovaca, 22, 399-410 (in Slovak with English summary).

Marko F., Vojtko R., Plašienka D., Sliva L., Jablonský J., Reichwalder P., Starek D., 2005: A contribution to the tectonics of the Periklippen zone near Zázrivá (Western Carpathians). Slovak Geol. Mag., 11, 1, 37-43.

Mojzeš A., Marko F., Porubčanová B., Bartošová A., 2017: Radon measurements in an area of tectonic zone: A case study in Central Slovakia. J. Environ. Radioact., 166, Part 2, 278-288, doi: 10.1016/j.jenvrad.2016.08.012. 
Moreno V., Bach J., Zarroca M., Font Ll., Roqué C., Linares R., 2018: Characterization of radon levels in soil and groundwater in the North Maladeta Fault Area (Central Pyrenees) and their effects on indoor radon concentration in a thermal spa. J. Environ. Radioact., 189, 1-13, doi: 10.1016/j.jenvrad.2018.03.001.

Müllerová M., Kozak K., Kovács T., Smetanová I., Csordás A., Grzadziel D., Holý K., Mazur J., Moravcsík A., Neznal M., Neznal M., 2016: Indoor radon survey in Visegrad countries. Appl. Radiat. Isot., 110, 124-128, doi: 10.1016/j.apradiso.2016 .01 .010 .

Neri M., Giammanco S., Ferrera E., Patanè G., Zanon V., 2011: Spatial distribution of soil radon as a tool to recognize active faulting on an active volcano: the example of Mt. Etna (Italy). J. Environ. Radioact., 102, 9, 863-870, doi : 10.1016/j.jenvrad .2011 .05 .002 .

Neri M., Giammanco S., Leonardi A., 2019: Preliminary Indoor Radon Measurements Near Faults Crossing Urban Areas of Mt. Etna Volcano (Italy). Front. Public Health, 7, 105, doi: 10.3389/fpubh.2019.00105.

Papaefthymiou H., Mavroudis A., Kritidis P., 2003: Indoor radon levels and influencing factors in houses of Patras, Greece. J. Environ. Radioact., 66, 3, 247-260, doi: 10.1016/S0265-931X (02) 00110-8.

Smetanová I., Mojzeš A., Marko F., Fekete K., 2018: Indoor radon survey - preliminary results from Sološnica village, Slovakia. In: Barnet I., Neznal M., Pacherová P. (Ed.): Proc. 14th Int. Workshop on Geological Aspects of Radon Risk Mapping, Prague, September 17-21, 143-148, ISBN: 978-80-01-06493-1.

Thinová L., Burian I., 2008: Effective dose assessment for workers in caves in the Czech Republic: experiments with passive radon detectors. Radiat. Prot. Dosim., 130, 1, 48-51, doi: 10.1093/rpd/ncn118.

Vičanová M., 2003: Utilisation of solid state nuclear track detectors in the solution of radon problems (Využitie detektorov stôp v pevnej fáze pri riešení radónovej problematiky). Ph.D. Thesis, Faculty of Mathematics, Physics and Informatics, Comenius University of Bratislava, 82 p. (in Slovak).

Vojtko R., Marko F., Preusser F., Madarás J., Kováčová M., 2011: Late Quarternary fault activity in the Western Carpathians: Evidence from the Vikartovce fault (Slovakia). Geol. Carpath., 62, 6, 563-574, doi: 10.2478/v10096-011-0040-9.

WHO, 2009: Handbook on Indoor Radon: A Public Health Perspective. World Health Organization, ISBN: 978-92-4-154767-3, 95 p. 